\title{
Pengaruh Pembatasan Pakan pada Tingkat yang Berbeda terhadap Performa dan Profil Lipid pada Broiler Umur Empat Puluh Dua Hari
}

\author{
Effects of Severe Level of Feed Restriction on Performance and Lipid Profiles in Forty Two \\ Days Broiler Chickens Age
}

\section{Urip Santoso}

\author{
Jurusan Peternakan, Fakultas Pertanian, Universitas Bengkulu \\ Jalan WR Supratman, Kandang Limun, Bengkulu 38371A \\ Telp.+62-736-21170 ext. 219, e-mail: santoso@unib.ac.id
}

\begin{abstract}
The present study was conducted to evaluate effects of severe level of feed restriction on performance and lipid profiles in broiler chickens. One group was fed ad libitum as the control group and the other six groups were fed $25 \%$ ad libitum (25\% multiplied by amount of feed intake of ad libitum chickens at the previous day) for 4 or 6 days, $50 \%$ ad libitum for 4 or 6 days, and $75 \%$ ad libitum for 4 or 6 days. Body weight gain, body weight and feed intake in broilers restricted at level of $25 \%$ ad libitum were significantly lower $(\mathrm{P}<0.05)$ than the control. Feed restriction did not significantly affect feed conversion ratio and leg abnormality $(\mathrm{P}>0.05)$. Feed restriction did not significantly affect $(\mathrm{P}<0.05)$ on fatty liver score, abdominal fat pad, cholesterol and triglyceride concentrations in serum, fatty liver score, and nutritional composition of liver, breast and leg meats. In conclusion, feed restriction at different severe had no effect on performance and lipid profiles in broilers aged forty two days.
\end{abstract}

Key words: Feed restriction, Broiler, Performance, Lipid profiles

\section{ABSTRAK}

Penelitian ini dilakukan untuk mengevaluasi pengaruh tingkat pembatasan pakan terhadap performa, profil lipid dan komposisi gizi dalam hati, daging dada dan paha pada ayam broiler. Satu kelompok broiler diberi pakan bebas (control) dan 6 kelompok perlakuan lainnya diberi pakan 25\% ad libitum, 50\% ad libitum atau $75 \%$ ad libitum masing-masing selama 4 atau 6 hari. Berat badan, pertambahan berat badan dan konsumsi pakan pada broiler yang dibatasi pakannya pada tingkat $25 \%$ ad libitum secara nyata lebih rendah $(\mathrm{P}>0,05)$ jika dibandingkan dengan control. Pembatasan pakan tidak berpengaruh secara nyata $(\mathrm{P}>0,05)$ terhadap konversi pakan, dan abnormalitas kaki $(\mathrm{P}<0.05)$. Pembatasan pakan berpengaruh tidak nyata $(\mathrm{P}>0,05)$ terhadap fatty liver score, lemak abdominal, kadar kolesterol dan trigliserida dalam serum, dan komposisi ngizi dari hati, daging dada dan paha. Sebagai kesimpulan bahwa pembatasan pakan tidak memperbaiki performa dan profil lemak pada ayam broiler umur empat puluh dua hari.

Kata kunci: Pembatasan pakan, Broiler, Performa, Profil lipid

\section{PENDAHULUAN}

Dewasa ini, industri broiler dihadapkan pada tuntutan konsumen yang menghendaki daging ayam dengan lemak rendah. Disisi lain, industri broiler juga harus secara terus menerus meningkatkan efisiensi produksinya agar mampu bersaing di pasar usaha. Salah satu upaya untuk memenuhi tuntutan di atas adalah dengan menerapkan program pembatasan pakan.
Pembatasan pakan telah terbukti mampu menurunkan kadar lemak dan sekaligus meningkatkan performa broiler pada umur 56 hari (Santoso, 2001, 2002a,b). Namun permasalahan muncul ketika dewasa ini broiler dijual pada umur 28-42 hari. Ballay et al. (1992) menemukan bahwa pembatasan pakan mampu meningkatkan performa ayam broiler pada umur 42 hari, Namun mereka tidak meneliti profil 
lemaknya. Padahal keberhasilan program pembatasan pakan adalah mampu menurunkan deposisi lemak tanpa menurunkan performa broiler pada umur potong (Plavnik dan Hurwits, 1985).

Berdasarkan pemikiran tersebut, maka penelitian ini dilakukan untuk mengevaluasi program pembatasan pakan terhadap performa, penimbunan lemak dan komposisi kimia daging pada ayam broiler umur 42 hari.

\section{MATERI DAN METODE}

Tiga ratus lima puluh ekor ayam broiler umur 1 hari (strain Arbor Acres) yang diperoleh dari penetasan komersial digunakan dalam penelitian ini. Dari umur 1 - 14 hari panas tambahan diberikan dengan menggunakan lampu gantung. Suhu kandang dipertahankan pada $32.5^{\circ} \mathrm{C}$ pada minggu pertama dan secara perlahan diturunkan sampai mencapai suhu ruang pada minggu kedua (Santoso et al., 1995). Broiler dipelihara dalam kandang kawat dalam kandang dengan pencahayaan terus menerus dan pakan dan air diberikan ad libitum. Pemeliharaan dalam penelitian ini sesuai dengan rekomendasi system pemeliharaan secara komersial. Broiler diberi pakan komersial periode starter dari umur 1 sampai 28 hari, dan pakan komersial finisher dari umur 29 sampai 42 hari. Komposisi gizi untuk pakan komersial telah dipublikasikan (Santoso, 2001).

Pada umur 7 hari, tiga ratus lima puluh ekor broiler dibagi ke dalam 7 kelompok - dimana setiap kelompok terdiri atas 3 kandang sebagai ulangan dan setiap ulangan berisi 10 ekor broiler. Satu kelompok broiler diberi pakan bebas (control) dan 6 kelompok perlakuan lainnya diberi pakan 25\% ad libitum, 50\% ad libitum atau $75 \%$ ad libitum masingmasing selama 4 atau 6 hari. (Santoso, 2002a). Pembatasan pakan dilakukan selama 6 hari, dan setelah itu diberi pakan ad libitum sampai umur 42 hari.

Pada umur 42 hari, 6 broiler (3 jantan dan 3 betina) pada setiap kelompok perlakuan diseleksi dan darah diambil dari vena sayap dengan menggunakan jarum suntik dan kemudian dipusingkan pada $600 \times g$ selama 10 menit. Serum yang diperoleh disimpan pada suhu $-30^{\circ} \mathrm{C}$ sampai analisis konsebtrasi trigliserida dan kolesterol. Setelah itu, broiler disembelih dengan menggunakan pisau dan lemak abdominal dan hati dikoleksi dan ditimbang. Daging dada dan paha diambil dan digiling sampai halus.

Kadar lemak, protein dan air dianalisis dengan menggunakan metode AOAC (1980). Konsentrasi kolesterol dan trigliserida serum dianalisis dengan menggunakan kit komersial (Bio Systems SA, Spain). Semua data dianalisis varians 
dan jika berbeda nyata diuji lanjut dengan Duncan's Multiple range Test (Duncan, 1955).

\section{HASIL DAN PEMBAHASAN}

Tabel 1 menunjukkan pengaruh pembatasan pakan terhadap performa ayam broiler. Hasil sidik ragam menunjukkan bahwa pembatasan pakan berpengaruh secara nyata $(\mathrm{P}<0,05)$ terhadap berat badan, pertambahan berat badan dan konsumsi ransum. Hasil uji lanjut menunjukkan bahwa berat badan, pertambahan berat badan dan konsumsi pakan pada broiler yang dibatasi pakannya pada tingkat $25 \%$ ad libitum secara nyata lebih rendah $(\mathrm{P}<0,05)$ jika dibandingkan dengan kontrol. Pembatasan pakan berpengaruh tidak nyata $(\mathrm{P}>0,05)$ terhadap konversi pakan, dan abnormalitas kaki $(\mathrm{P}<0.05)$.

Tabel 1. Pengaruh pembatasan pakan terhadap performa ayam broiler umur 42 hari

\begin{tabular}{lccccccc}
\hline & & \multicolumn{3}{c}{4 hari } & \multicolumn{4}{c}{6 hari } \\
\cline { 2 - 8 } & Ad libitum & $\begin{array}{c}25 \% \\
\text { ad lib }\end{array}$ & $\begin{array}{c}50 \% \\
\text { ad lib }\end{array}$ & $\begin{array}{c}75 \% \\
\text { ad lib }\end{array}$ & $\begin{array}{c}25 \% \text { ad } \\
\text { lib }\end{array}$ & $\begin{array}{c}50 \% \\
\text { ad lib }\end{array}$ & $\begin{array}{c}75 \% \\
\text { ad lib }\end{array}$ \\
\hline BB, g/ekor & 1791 & 1722 & 1746 & 1806 & $1687^{*}$ & 1700 & 1756 \\
PBB, g/ekor & 1678 & 1613 & 1639 & 1697 & $1578^{*}$ & 1592 & 1645 \\
Konsumsi, g/ekor & 2955 & 2737 & 2840 & 2990 & $2669^{*}$ & 2772 & 2968 \\
Konversi pakan & 1.61 & 1.60 & 1.59 & 1.57 & 1.60 & 1.58 & 1.55 \\
Abnormalitas kaki & 1.18 & 1.08 & 1.04 & 1.04 & 1.0 & 1.06 & 1.18 \\
\hline BB=berat badan, PBB=pertambahan berat badan, *berbeda nyata(P<0.05) terhadap kontrol
\end{tabular}

Tabel 2 menyajikan data pengaruh pembatasan pakan terhadap komposisi gizi dalam hati, daging dada dan paha. Hasil sidik ragam menunjukkan bahwa pembatasan pakan berpengaruh tidak nyata $(\mathrm{P}>0,05)$ terhadap kadar air, protein, lemak dan abu dalam hati, daging dada dan paha.

Tabel 3 menyajikan data pengaruh pembatasan pakan terdapa konsentrasi koletserol dan trigliserida dalam serum, fatty live srcore dan lemak abdominal. Hasil sidik ragam menunjukkan bahwa pembatasan pakan berpengaruh tidak nyata $(\mathrm{P}>0,05)$ terhadap fatty liver score, lemak abdominal, kadar kolesterol dan trigliserida dalam serum. 
Tabel 2. Pengaruh pembatasan pakan terhadap komposisi gizi dalam hati, daging dada dan paha pada broiler umur 42 hari

\begin{tabular}{llllllll}
\hline & & \multicolumn{3}{c}{4 hari } & \multicolumn{3}{c}{6 hari } \\
\cline { 3 - 8 } & $\begin{array}{c}\text { Ad } \\
\text { libitum }\end{array}$ & $\begin{array}{c}25 \% \\
\text { ad lib }\end{array}$ & $\begin{array}{c}50 \% \\
\text { ad lib }\end{array}$ & $\begin{array}{c}75 \% \\
\text { ad lib }\end{array}$ & $\begin{array}{c}25 \% \\
\text { ad lib }\end{array}$ & $\begin{array}{c}50 \% \\
\text { ad lib }\end{array}$ & $\begin{array}{c}75 \% \\
\text { ad lib }\end{array}$ \\
\hline Hati (\%) & & & & & & & \\
$\quad$ Air & 73.2 & 70.0 & 70.5 & 70.4 & 71.2 & 71.2 & 70.1 \\
$\quad$ Protein & 22.0 & 22.3 & 21.8 & 20.7 & 22.7 & 21.5 & 21.6 \\
$\quad$ Lemak & 3.9 & 3.8 & 4.0 & 4.9 & 4.2 & 4.0 & 4.0 \\
$\quad$ Abu & 0.9 & 3.9 & 3.7 & 4.2 & 1.9 & 3.5 & 4.3 \\
Daging dada (\%) & & & & & & & \\
$\quad$ Air & 73.3 & 72.3 & 72.4 & 72.3 & 72.0 & 72.4 & 72.2 \\
$\quad$ Protein & 24.5 & 24.5 & 24.5 & 24.5 & 24.5 & 24.4 & 24.5 \\
$\quad$ Lemak & 1.8 & 1.4 & 1.2 & 1.1 & 1.3 & 1.3 & 1.0 \\
$\quad$ Abu & 0.4 & 1.9 & 1.9 & 2.1 & 2.3 & 1.8 & 2.3 \\
Daging paha (\%) & & & & & & & \\
$\quad$ Air & 63.9 & 63.8 & 63.7 & 63.3 & 63.8 & 63.4 & 63.4 \\
$\quad$ Protein & 22.9 & 22.9 & 23.1 & 22.9 & 23.0 & 23.0 & 23.1 \\
$\quad$ Lemak & 10.8 & 10.5 & 10.3 & 10.3 & 10.7 & 10.7 & 10.0 \\
$\quad$ Abu & 2.4 & 2.8 & 3.0 & 3.5 & 2.5 & 2.9 & 3.5 \\
\hline
\end{tabular}

Tabel 3. Pengaruh pembatasan pakan terhadap konsentrasi kolesterol dan trigliserida dalam serum, lemak abdominal dan fatty liver score pada ayam broiler umur 42 hari

\begin{tabular}{llllllll}
\hline & & \multicolumn{3}{c}{4 hari } & \multicolumn{3}{c}{6 hari } \\
\cline { 3 - 8 } & $\begin{array}{c}\text { Ad } \\
\text { libitum }\end{array}$ & $\begin{array}{l}25 \% \\
\text { ad lib }\end{array}$ & $\begin{array}{l}50 \% \\
\text { ad lib }\end{array}$ & $\begin{array}{l}75 \% \\
\text { ad lib }\end{array}$ & $\begin{array}{l}25 \% \\
\text { ad lib }\end{array}$ & $\begin{array}{l}50 \% \\
\text { ad lib }\end{array}$ & $\begin{array}{l}75 \% \\
\text { ad lib }\end{array}$ \\
\hline Trigliserida (mg/dl) & 16.7 & 17.1 & 16.1 & 13.9 & 17.3 & 12.2 & 12.7 \\
Kolesterol (mg/dl) & 147.2 & 147.2 & 190.2 & 183.6 & 162.8 & 146.0 & 111.2 \\
Lemak abdominal (\%BB) & 2.62 & 1.97 & 2.03 & 2.28 & 1.99 & 2.32 & 2.43 \\
fatty liver score & 2.03 & 2.20 & 2.40 & 2.59 & 2.28 & 2.18 & 2.23 \\
\hline
\end{tabular}

$\mathrm{BB}=$ berat badan

Tabel 4 menyajikan data tentang pengaruh pembatasan pakan terhadap berat organ dalam dan bagian karkas pada ayam broiler. Hasil sidik ragam menunjukkan bahwa pembatasan pakan berpengaruh tidak nyata terhadap berat hati, usus, rempelo, limfa, jantung dan berat karkas, sayap, dada, paha dan punggung.

Hasil penelitian menunjukkan bahwa tingkat layanan pembatasan pakan berpengaruh terhadap compensatory growth pada broiler yang diberi pakan $25 \%$ ad libitum selama 6 hari, yaitu tidak mampu memperlihatkan compensatory growth, sedangkan perlakuan lainnya mampu menunjukkan compensatory growth. Penelitian ini sesuai dengan hasil penelitian Plavnik dan Hurwitz (1985, 1988) dan Su et al. (1999) pada umur 56 hari, dan . Ballay et al. (1992) pada umur 42 hari. Hasil penelitian ini menunjukkan bahwa pada broiler campuran, broiler tidak 
perlu dibatasi pakannya pada tingkat hidup pokok sebagaimana yang ditemukan oleh Plavnik and Hurwitz (1985). Ketidakmampuan kelompok broiler dengan $25 \%$ ad lbitum selama 6 hari memperlihatkan compensatory growth menunjukkan bahwa tingkat layanan pembatasan pakan tersebut terlalu lama, sebab ketika tingkat layanan yang sama tetapi diberikan selama 4 hari, broiler mampu menunjukkan compenasatory growth secara sempurna.

Tabel 4. Pengaruh pembatasan pakan terhadap berat organ dalam dan berat bagian karkas pada broiler umur 42 hari

\begin{tabular}{llllllll}
\hline & & \multicolumn{3}{c}{4 hari } & \multicolumn{3}{c}{6 hari } \\
\cline { 3 - 8 } & Ad libitum & $\begin{array}{r}25 \% \\
\text { ad lib }\end{array}$ & $\begin{array}{r}50 \% \\
\text { ad lib }\end{array}$ & $\begin{array}{r}75 \% \\
\text { ad lib }\end{array}$ & $\begin{array}{r}25 \% \\
\text { ad lib }\end{array}$ & $\begin{array}{r}50 \% \\
\text { ad lib }\end{array}$ & $\begin{array}{c}75 \% \\
\text { ad lib }\end{array}$ \\
\hline Organ dalam & & & & & & & \\
$\quad$ Usus & 1.75 & 2.04 & 1.75 & 2.36 & 1.79 & 1.93 & 1.80 \\
$\quad$ Rempelo & 1.07 & 1.07 & 1.03 & 1.04 & 1.23 & 1.08 & 1.19 \\
$\quad$ Limfa & 0.25 & 0.22 & 0.20 & 0.21 & 0.21 & 0.29 & 0.23 \\
$\quad$ Hati & 2.02 & 2.27 & 2.55 & 2.62 & 2.29 & 2.50 & 2.41 \\
$\quad$ Jantung & 0.34 & 0.35 & 0.36 & 0.37 & 0.39 & 0.44 & 0.44 \\
Karkas & & & & & & & \\
$\quad$ Berat karkas & 69.8 & 66.6 & 67.3 & 67.2 & 66.7 & 66.5 & 68.6 \\
$\quad$ Paha & 34.5 & 36.0 & 35.7 & 34.7 & 35.8 & 35.5 & 34.7 \\
$\quad$ Dada & 28.4 & 27.6 & 27.9 & 28.9 & 28.0 & 29.5 & 28.0 \\
$\quad$ Punggung & 24.6 & 23.7 & 24.5 & 24.3 & 23.4 & 22.6 & 24.9 \\
$\quad$ Sayap & 12.3 & 12.6 & 11.9 & 12.4 & 12.7 & 12.3 & 12.5 \\
\hline
\end{tabular}

Pembatasan pakan pada berbagai tingkat layanan tidak menurunkan profil lemak pada ayam broiler umur 42 hari. Hasil ini berbeda dengan hasil penelitian Santoso (2002b) yang menemukan bahwa pembatasan pakan pada berbagai umur awal pembatasan menurunkan profil lemak pada broiler umur 56 hari. Perbedaan ini disebabkan oleh perbedaan umur potong dan strain. Ini berarti bahwa program pembatasan pakan dalam penelitian ini tidak mampu menurunkan deposisi lemak pada ayam broiler umur 42 hari.
Pembatasan pakan tidak berdampak negatif terhadap organ dalam dan bagian karkas. Ini berarti tingkat layanan pembatasan pakan dalam penelitian ini aman jika diterapkan pada industri peternakan broiler.

\section{KESIMPULAN}

Dapat disimpulkan bahwa pembatasan pakan menghasilkan performa dan profil lemak broiler yang relatif sama dengan broiler yang diberi pakan ad libitum (bebas) pada broiler umur 42 hari. 


\section{DAFTAR PUSTAKA}

AOAC. 1980. Official Method of Analysis. 13rd rev. ed. Association of Official Chemists.

Ballay, M., E. A. Dunnington, W. B. Gross and P. B. Siegel. 1992. Restricted feeding and broiler performance: Age at initiation and length of restriction. Poult. Sci. 71:440447.

Duncan, D. B. 1955. Multiple range and multiple F test. Biometrics, 11:142.

Plavnik, I. and S. Hurwitz. 1985. The performance of broiler chickens during and following a severe feed restriction at an early age. Poult. Sci. 68:1118-1125.

Plavnik, I. and S. Hurwitz. 1988. Early feed restriction in chickens: effect of age, duration, and sex. Poultry Sci. 67: 1407-1413.

Santoso, U., K. Tanaka and S. Ohtani. 1995. Early skip-a-day feeding of female broiler chickens fed highprotein realimentation diets. Performance and body composition. Poult. Sci. 74:494501 .

Santoso, U. 2001. Effects of early feed restriction on growth, fat accumulation and meat composition in unsexed broiler chickens. Asian-Aust. J. Anim. Sci. 14:1585-1591.

Santoso, U. 2002a. Effects of early feed restriction on the occurrence of compensatory growth, feed conversion efficiency, leg abnormality and mortality in unsexed broiler chickens reared in cages. Asian-Aust. J. Anim. Sci. 15 : 1319-1325.

Santoso, U. 2002b. Effects of early feed restriction on breast and leg meat composition and plasma lipid concentration in unsexed broiler chickens reared in cages. AsianAust. J. Anim. Sci. 2002. 15: 1475-1481.

Su, G., P. Sorensen and S. C. Kestin. 1999. Meal feeding is more effective than early feed restriction at reducing the prevalence of leg weakness in broiler chickens. Poult. Sci. 78:949-955. 